\title{
EARLY FEEDING PRACTICES AND THEIR DETERMINANTS: NATIONAL FOOD, NUTRITION AND PHYSICAL ACTIVITY SURVEY 2015-2016
}

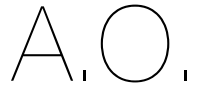

ARTIGO ORIGINAL

1 EPIUnit - Instituto de Saúde Pública da Universidade do Porto, Rua das Taipas, n. ${ }^{\circ} 135$, 4050-091 Porto, Portugal

2 Departamento de Ciências da Saúde Pública e Forenses, e Educação Médica da Faculdade de Medicina da Universidade do Porto,

Rua Doutor Plácido da

Costa,

4200-450 Porto, Portugal

${ }^{3}$ Faculdade de Ciências da Nutrição e Alimentação da Universidade do Porto, Rua Dr. Roberto Frias, 4200-465 Porto, Portugal

*Endereço para correspondência:

\section{Carla Lopes}

Departamento de Ciências da Saúde Pública e Forenses, e Educação Médica da Faculdade de Medicina da Universidade do Porto,

Rua Doutor Plácido da Costa, 4200-450 Porto, Portugal carlal@med.up.pt

Histórico do artigo:

Recebido a 5 de julho de 2019 Aceite a 16 de setembro de 2019

\author{
PRÁTICAS ALIMENTARES NOS PRIMEIROS ANOS DE VIDA E \\ SEUS DETERMINANTES: INQUÉRITO ALIMENTAR NACIONAL \\ E ATIVIDADE FÍSICA 2015-2016
}

Sara Silva'; Daniela Correia ${ }^{1,2}$; Milton Severo ${ }^{1,2}$; Andreia Oliveira ${ }^{1,2}$; Duarte Torres ${ }^{1,3}$; Carla Lopes ${ }^{1,2 *}$

\section{ABSTRACT}

INTRODUCTION: Feeding practices in the first two years of life influence the child's growth and future health. Updated information on factors associated with breastfeeding and complementary feeding practices is needed to support maternal and child health policies. OBJECTIVES: To describe breastfeeding and complementary feeding practices and associated factors on a representative sample of Portuguese children.

METHODOLOGY: The study includes a sample of 904 children from 3 to 35 months from the National Food, Nutrition and Physical Activity Survey (IAN-AF 2015-2016). A questionnaire about feeding practices during the first years of life was applied to parents/ caregivers. Survival analysis was used to estimate proportions and a Cox regressions hazard model was used to estimate associations. RESULTS: The proportion of children never breastfed was around 6\% and 30\% stopped breastfeeding before 4 months. The breastfeeding duration was longer in older, less educated and unemployed mothers. Only $3.3 \%$ of infants started complementary feeding before 4 months. Weaning started with a vegetable soup in $66 \%$ of infants. Around $7 \%$ of children drunk cow milk before completion of 12 months of age and the risk of early consumption was increased in infants from less educated and unemployed mothers. Children assisted by a primary health care physician had a higher risk of early introduction of cow milk in comparison with the paediatrician.

CONCLUSIONS: Among Portuguese children, early feeding practices seem to be globally according to recommendations. An early stop of breastfeeding is more frequent in higher educated women and active workers. Other practices that could compromise children's growth such as the early introduction of cow milk is more frequent in socio-economic disadvantaged families.

\section{KEYWORDS}

Breastfeeding, Complementary feeding, Cow milk, Determinants, Early feeding practices

RESUMO

INTRODUÇÃO: As práticas alimentares nos primeiros 2 anos de vida condicionam o crescimento e a saúde futura da criança. Informação atualizada sobre que fatores estão associados às práticas de aleitamento materno e de diversificação alimentar é necessária para apoiar políticas de saúde materno-infantil.

OBJETIVOS: Caraterizar a prática de aleitamento materno e diversificação alimentar e fatores associados numa amostra representativa de crianças Portuguesas.

METOdologiA: O estudo incluiu uma amostra de 904 crianças dos 3 aos 35 meses, avaliadas no Inquérito Alimentar Nacional e de Atividade Física (IAN-AF 2015-2016). O questionário sobre práticas alimentares no primeiro ano de vida foi aplicado aos pais/ cuidadores. Para estimar as proporções usou-se análise de sobrevivência e para estimar as associações utilizaram-se modelos de regressão de Cox.

RESULTADOS: A proporção de crianças que nunca foi amamentada é de cerca de $6 \%$ e $30 \%$ deixou de ser amamentada antes dos 4 meses. A duração do aleitamento materno foi maior em mães mais velhas, menos escolarizadas e desempregadas. Apenas 3,3\% das crianças iniciaram a diversificação alimentar antes dos 4 meses de idade. Em 66\% dos casos, o primeiro alimento introduzido foi a sopa de vegetais. Pelo menos $7 \%$ das crianças consumiram leite de vaca antes dos 12 meses de idade e a probabilidade de introdução precoce do mesmo foi maior no caso de mães menos escolarizadas e desempregadas. Também as crianças assistidas pelo médico de família apresentaram maior risco de introdução precoce de leite de vaca comparativamente a crianças assistidas pelo pediatra.

CONCLUSÕES: Entre as crianças portuguesas as práticas alimentares parecem ocorrer, globalmente, de acordo com as recomendações. $\mathrm{O}$ abandono precoce do aleitamento materno é mais frequente em mães mais escolarizadas e ativas profissionalmente. Outras práticas que podem comprometer o crescimento saudável da criança, como a introdução precoce do leite de vaca, são mais frequentes em grupos socioeconómicos mais desfavorecidos.

PALAVRAS-CHAVE

Aleitamento materno, Diversificação alimentar, Leite de vaca, Determinantes, Práticas alimentares precoces 


\section{INTRODUCTION}

The first 1000 days of life, from conception to 2 years of age, is described as the most important period in programming future health (1). Inadequate early feeding practices, namely short duration of breastfeeding (BF), use of human milk substitutes and inadequate timing of complementary feeding onset have been related with dietary nutrient inadequacy and commitment of normal childhood growth and development (2).

The World Health Organization (WHO) recommends exclusive breastfeeding (EBF) - the infant is breastfed with no supplemental liquids or solid food other than medications or vitamins, during the first 6 months of life (3). The European Society for Paediatric Gastroenterology, Hepatology and Nutrition (ESPGHAN) (4), the European Food Safety Authority (EFSA) (5) and the Portuguese Society of Paediatrics (6) recommend $\mathrm{EBF}$ for approximately 6 months and the introduction of complementary feeding between 17 and 26 weeks of age (7).

According to the $\mathrm{WHO}, \mathrm{BF}$ should continue, at least, until to 2 years of age (3). However, other entities, namely the Portuguese Society of Paediatrics recommends BF, at least, during the first year of life (8). Likewise, the ESPGHAN supports that BF should be continued for long as desired by the mother and child due to the European low burden of infectious diseases and the lack of data about the optimal duration of $\mathrm{BF}(4)$.

Despite the recognized beneficial effects of breastfeeding to child and mother's health, for around 5-6 months it is important to introduce other foods and liquids in order to meet all nutritional requirements of the child (7). Appropriate complementary feeding should be timely, nutritionally adequate and safe (9) and should be included in a healthy and varied diet taking into account traditions and feeding patterns (6, 7). The preference for healthy foods could be developed during infancy and could persist up to 6 years later (7). The Portuguese Society of Paediatrics, according to healthy growth patterns, recommends starting complementary feeding with a vegetable soup (5th and 6th months), followed by fruit, meat and fish around the 6th month and the introduction of cow milk only after 12 months of age (6).

The early consumption of cow milk has health negative effects (10). Extent evidence relates the early cow milk introduction during infancy with lower iron stores and a higher probability of iron deficiency (11) (cow milk is a poor source of iron (7) and calcium and casein content inhibits non-heme iron absorption (12)).

Socioeconomic, educational and lifestyle factors were previously associated with breastfeeding (4) and with complementary feeding practices (13). Feeding practices during infancy are significantly associated with maternal characteristics (breastfeeding initiation and duration are positively associated with higher education $(14,15)$, being married (14) and multiparity (15)) and child characteristics (low birth weight (15) and being in a day-care (14) are positively and negatively, respectively, associated with the duration of breastfeeding).

Data about complementary feeding practices in European countries are limited (7) and few studies have analysed the influence of maternal characteristics on the timing of complementary feeding (16) and type of food introduced (7) as well as the consumption of cow milk before one year of age (17) in representative national samples. The aim of this study is to characterize early feeding practices and associated factors using data from the National Food, Nutrition and Physical Activity Survey (IAN-AF 2015-2016).

\section{METHODOLOGY}

The IAN-AF 2015-2016 methodology is fully described elsewhere (18, 19). Briefly, the IAN-AF 2015-2016 used a two-stage sampling design to obtain a representative sample of the Portuguese general population, aged between 3 months and 84 years of age, based on the National Heath Registry. Firstly, Primary Health Care Units in each region (NUTS II) were randomly selected and then a fixed number of individuals by sex and age groups were randomly selected among those registered in each Primary Health Care Unit.

The final sample included 6553 individuals who attended one interview, 6429 with at least one dietary assessment (participation among eligible individuals: $33.4 \%$ ) and 5811 with two complete assessments (29.6\%). Those who refused to participate were invited to complete a refusal questionnaire.

For children up to 2 years-old ( $n=911$ ), the participation rate was $54.9 \%$ and $48.6 \%$ for the first and second interviews, respectively. The final sample of this study includes 904 children, aged between 3 and 35 months, with complete information to key variables.

\section{Data collection}

The IAN-AF 2015-2016 included the evaluation of several dimensions, using methods and protocols harmonized for the Pan-European Food Consumption Survey (20). Two computer-assisted personal interviews were conducted during 12 months and the information was collected in an electronic platform ("You Eat\&Move").

For children aged between 3 and 35 months, the assessed dimensions were sociodemographic, general health, eating behaviours, anthropometry and two food diaries filled by parents or caregivers followed by an interview in the following day. Anthropometrics included weight/length recorded from the child health booklet and objective measurements during the interview. For the current analysis only the objective measurements were considered. Overweight and obesity were defined based on the cut-off points recommended by the WHO specific by sex and age (two and three times the standard-deviation, respectively) (21).

\section{Ethical procedures}

The IAN-AF 2015-2016 was approved by the National Commission for Data Protection, the Ethical Committee of the Institute of Public Health of the University of Porto and by the Ethical Commissions of the Regional Administrations of Health. All participants were asked to provide their written informed consent for participation. Written agreements from the parents were required for participants under 18 years-old.

\section{Statistical Analysis}

Survival analysis was performed to estimate breastfeeding, breastfeeding substitutes and complementary feeding practices from 3 to 35 months. Data was weighted according to the complex sampling design used in the IAN-AF $(18,19)$. Nelson-Aeler method was used to obtain the survival function. Differences between survival curves were tested using the log-rank test.

Associations between breastfeeding cessation, beginning of complementary feeding and cow milk introduction with socioeconomic and health factors were estimated using time-dependent Cox regression hazard models, after the proportional hazards assumption being tested and not verified for some variables of interest. The factors considered were child's gender and age, living with siblings, type of health assistance and having a disease that requires regular health care, as well as maternal education and employment status. A crude and a complete model were considered. Tests for interaction between co-variables were not significant and therefore not included in final hazard models. 
A significance level of $5 \%$ was assumed as well as independence between observations. Analyses were performed using the R software (The R Project for Statistical Computing), version 3.4.1, and Statistical Package for the Social Sciences (SPSS), version 24.0.

\section{RESULTS}

Children's characteristics are described in Table 1. Of the 904 children, $50.4 \%$ were female, $70.6 \%$ were aged 1 to 2 years, and $7.8 \%$ and $1.6 \%$ were overweight and obese, respectively. Mothers were aged more frequently between $30-35$ years of age (44.7\%). Higher education is more frequent among mothers than fathers ( $41.8 \%$ vs. $28.8 \%)$, and both were mostly employed.

The prevalence of BF, the use of milk-substitutes and complementary feeding practice is described in Table 2 . Around $6 \%$ of children were never breastfed and $64.9 \%$ were breastfed for less than 12 months.

\section{Table 1}

Socioeconomic and health-related characteristics of children aged between 3 and 35 months and their parents, IAN-AF 2015-2016

\begin{tabular}{|c|c|c|}
\hline $\mathrm{N}(\%)$ & \multicolumn{2}{|c|}{$\begin{array}{l}\text { PARTICIPANTS } \\
\qquad(\mathrm{N}=904)\end{array}$} \\
\hline \multicolumn{3}{|l|}{ Sex } \\
\hline Female & \multicolumn{2}{|c|}{$456(50.4 \%)$} \\
\hline Male & \multicolumn{2}{|c|}{$448(49.6 \%)$} \\
\hline \multicolumn{3}{|l|}{ Age group } \\
\hline$<1$ year-old & \multicolumn{2}{|c|}{$266(29.4 \%)$} \\
\hline $1-2$ years-old & \multicolumn{2}{|c|}{$638(70.6 \%)$} \\
\hline \multicolumn{3}{|l|}{ Nationality } \\
\hline Portuguese & \multicolumn{2}{|c|}{899 (99.4\%) } \\
\hline Other & \multicolumn{2}{|c|}{$5(0.5 \%)$} \\
\hline \multicolumn{3}{|l|}{ Household composition } \\
\hline Less than 3 members & \multicolumn{2}{|c|}{$23(2.7 \%)$} \\
\hline 3-5 members & \multicolumn{2}{|c|}{$760(90.4 \%)$} \\
\hline More than 5 members & \multicolumn{2}{|c|}{58 (6.9\%) } \\
\hline \multicolumn{3}{|l|}{ Living with siblings } \\
\hline Yes & \multicolumn{2}{|c|}{$434(48.0 \%)$} \\
\hline \multicolumn{3}{|l|}{ BMI classes $^{a}$} \\
\hline Low/Normal weight & \multicolumn{2}{|c|}{$788(90.6 \%)$} \\
\hline Overweight & \multicolumn{2}{|c|}{$68(7.8 \%)$} \\
\hline Obesity & \multicolumn{2}{|c|}{$14(1.6 \%)$} \\
\hline \multicolumn{3}{|l|}{ Chronic disease $^{\mathrm{b}}$} \\
\hline Yes & \multicolumn{2}{|c|}{$99(11.0 \%)$} \\
\hline \multicolumn{3}{|l|}{ Health assistance } \\
\hline Paediatrician & \multicolumn{2}{|c|}{$209(23.2 \%)$} \\
\hline Primary health care physician & \multicolumn{2}{|c|}{$310(34.4 \%)$} \\
\hline Both & \multicolumn{2}{|c|}{$381(42.3 \%)$} \\
\hline & Mother & Father \\
\hline \multicolumn{3}{|l|}{ Age } \\
\hline$<30$ years-old & $197(25.0 \%)$ & $98(15.1 \%)$ \\
\hline 30-35 years-old & $352(44.7 \%)$ & 224 (34.5\%) \\
\hline$>35$ years-old & $239(30.3 \%)$ & $327(50.4 \%)$ \\
\hline \multicolumn{3}{|l|}{ Educational level } \\
\hline Non-higher education & $524(58.2 \%)$ & $644(71.2 \%)$ \\
\hline Higher education & $377(41.8 \%)$ & $260(28.8 \%)$ \\
\hline Nationality & & \\
\hline Portuguese & $856(94.7 \%)$ & $867(95.9 \%)$ \\
\hline Other & $48(5.3 \%)$ & $37(4.1 \%)$ \\
\hline Employment situation & & \\
\hline Employed (for remuneration or profit) & $683(75.6 \%)$ & $817(90.4 \%)$ \\
\hline Unemployed or other & $174(19.2 \%)$ & $71(7.9 \%)$ \\
\hline
\end{tabular}

Approximately $46 \%$ of children were exclusively breastfed for less than 4 months and only $21.6 \%$ during 6 or more months. Almost $80 \%$ of children have consumed formula milk and $63.8 \%$ "growth" milk before 36 months. The early introduction of cow milk, before 12 months of age, was observed in $6.5 \%$ of children. Most children started complementary feeding between the age of 4 and 5 months, and 3.3\% before 4 months of age. The most common first food during weaning was vegetable soup (66.3\%) followed by infant cereals (25.8\%). The median age of introduction of soup was 5 months and 6 months of infant cereals and fruits. The introduction of meat only occurred after the 9 months of age for $10 \%$ of children, as well as fish, after the age of 11 months. At least $75 \%$ of children were introduced to the yogurt before 9 months of age. The consumption of fruit juices, fruit nectars, breakfast cereals, desserts, and soft drinks was observed, mostly, after the first year of age. However, $10 \%$ of children have started with soft drinks before 12 months and at 30 months $50 \%$ of children have already tasted this type of sugary beverages.

Table 3 describes the association of mother's sociodemographic factors and child's health status with BF duration, the age of complementary feeding starting and the early introduction of cow milk. Children whose mothers were aged over 35 years showed lower risk of breastfeed cessation when compared to children whose mothers were less

\section{Table 2}

Prevalence of breastfeeding, breastfeeding substitutes and complementary feeding practices in Portuguese children aged between 3 and 35 months, IAN-AF 2015-2016

\begin{tabular}{|c|c|}
\hline & $\%(95 \% \mathrm{Cl})$ \\
\hline Exclusive breastfeeding duration $\left({ }^{*}\right)$ & $91.1(88.4 ; 93.9)$ \\
\hline Never & $8.9(6.1 ; 11.6)$ \\
\hline$<4$ months & $45.9(41.3 ; 50.1)$ \\
\hline$<5$ months & $50.3(43.5 ; 56.3)$ \\
\hline$<6$ months & $78.4(75.3 ; 81.1)$ \\
\hline$\geq 6$ months & $21.6(18.9 ; 24.7)$ \\
\hline Total breastfeeding duration $(*)$ & $94.1(91.6 ; 96.7)$ \\
\hline Never & $5.9(3.3 ; 8.4)$ \\
\hline$<4$ months & $30.2(25.4 ; 34.6)$ \\
\hline$<5$ months & $34.3(29.0 ; 39.1)$ \\
\hline$<6$ months & $39.3(33.6 ; 44.5)$ \\
\hline$<12$ months & $64.9(58.5 ; 70.33)$ \\
\hline$\geq 12$ months & $35.1(29.7 ; 41.5)$ \\
\hline Use of infant formula before 36 months ( $\left.{ }^{*}\right)$ & $78.4(73.9 ; 82.1)$ \\
\hline$<4$ months & $46.4(41.3 ; 51.1)$ \\
\hline Use of growth milk before 36 months $\left(^{*}\right)$ & $63.8(54.8 ; 71.0)$ \\
\hline $\begin{array}{l}\text { Introduction to cow milk before } 36 \\
\text { months }\left(^{*}\right)\end{array}$ & 96.6 (93.3; 98.1) \\
\hline$<6$ months & $1.0(0.4 ; 1.6)$ \\
\hline$<12$ months & $6.5(4.0 ; 8.9)$ \\
\hline$<24$ months & $70.9(62.1 ; 77.7)$ \\
\hline \multicolumn{2}{|l|}{$\begin{array}{l}\text { Age of introduction of complementary } \\
\text { feeding }(*)\end{array}$} \\
\hline$<4$ months & $3.3(1.7 ; 4.8)$ \\
\hline$<5$ months & $38.3(34.6 ; 41.8)$ \\
\hline$<6$ months & $63.2(59.4 ; 66.7)$ \\
\hline$\geq 6$ months & $36.8(33.3 ; 40.6)$ \\
\hline \multicolumn{2}{|l|}{$\begin{array}{l}\text { First food introduced at complementary } \\
\text { feeding }\left(^{\star \star)}\right.\end{array}$} \\
\hline Infant cereals & $25.8(21.1 ; 30.5)$ \\
\hline Soup & $66.3(61.0 ; 71.5)$ \\
\hline Fruit & $6.5(4.0 ; 9.0)$ \\
\hline Other & $1.4(0.0 ; 2.8)$ \\
\hline
\end{tabular}


Hazard Ratios (HR) for breastfeeding cessation, beginning of complementary feeding and early cow milk introduction ( $<12$ months), according to sociodemographic and health data

\begin{tabular}{|c|c|c|c|c|c|c|}
\hline & \multicolumn{2}{|c|}{$\begin{array}{c}\text { BREASTFEEDING CESSATION } \\
\text { HR }(95 \% \mathrm{CI}) \\
\end{array}$} & \multicolumn{2}{|c|}{$\begin{array}{l}\text { BEGINNING OF COMPLEMENTARY FEEDING } \\
\text { HR }(95 \% \mathrm{CI})\end{array}$} & \multicolumn{2}{|c|}{$\begin{array}{c}\text { COW MILK INTRODUCTION } \\
\text { HR }(95 \% \mathrm{CI})\end{array}$} \\
\hline & CRUDE & ADJUSTED ${ }^{\mathrm{a}}$ & CRUDE & ADJUSTED & CRUDE & ADJUSTEDa \\
\hline \multicolumn{7}{|l|}{ Child sex } \\
\hline Female & ref & ref & ref & ref & ref & ref \\
\hline Male & $0.95(0.82 ; 1.11)$ & $0.90(0.77 ; 1.06)$ & $1.11(0.97 ; 1.27)$ & $1.12(0.97 ; 1.29)$ & $1.36(0.94 ; 1.37)$ & $1.04(0.85 ; 1.27)$ \\
\hline \multicolumn{7}{|l|}{ Living with siblings } \\
\hline No & ref & ref & ref & ref & ref & ref \\
\hline Yes & $0.87(0.75 ; 1.01)$ & $0.95(0.79 ; 1.13)$ & $1.03(0.91 ; 1.18)$ & $1.06(0.91 ; 1.24)$ & $1.26(1.04 ; 1.51)$ & $1.32(1.06 ; 1.64)$ \\
\hline \multicolumn{7}{|l|}{ Mother's age } \\
\hline$<30$ years & ref & ref & ref & ref & ref & ref \\
\hline $30-35$ years & $0.78(0.65 ; 0.96)$ & $0.89(0.72 ; 1.09)$ & $0.97(0.82 ; 1.16)$ & $0.94(0.78 ; 1.14)$ & $0.78(0.61 ; 1.00)$ & $0.90(0.70 ; 1.17)$ \\
\hline$>35$ years & $0.69(0.56 ; 0.86)$ & $0.77(0.61 ; 0.99)$ & $0.97(0.80 ; 1.17)$ & $0.92(0.74 ; 1.14)$ & $0.71(0.54 ; 0.92)$ & $0.82(0.60 ; 1.10)$ \\
\hline \multicolumn{7}{|l|}{ Mother's educational level } \\
\hline Non-higher education & ref & ref & ref & ref & ref & ref \\
\hline Higher education & $1.17(0.93 ; 1.48)$ & $1.15(0.88 ; 1.50)$ & $1.57(0.91 ; 2.74)$ & $1.52(0.84 ; 2.78)$ & $0.56(0.45 ; 0.70)$ & $0.65(0.50 ; 0.85)$ \\
\hline $\begin{array}{l}\text { Higher education } \mathrm{x} \\
{\text { child's age } \mathrm{e}^{\mathrm{b}}}\end{array}$ & $1.48(1.27 ; 1.72)$ & $1.46(1.24 ; 1.72)$ & $0.88(0.48 ; 1.61)$ & $1.50(0.82 ; 2.76)$ & $2.85(1.43 ; 5.67)$ & $2.98(1.43 ; 6.21)$ \\
\hline \multicolumn{7}{|c|}{ Mother's employment status } \\
\hline $\begin{array}{l}\text { Working (for } \\
\text { remuneration or profit) }\end{array}$ & ref & ref & ref & ref & ref & ref \\
\hline $\begin{array}{l}\text { Not working or other } \\
\text { condition }\end{array}$ & $0.64(0.48 ; 0.86)$ & $0.62(0.45 ; 0.85)$ & $0.80(0.44 ; 1.44)$ & $0.82(0.43 ; 1.55)$ & $1.51(1.22 ; 1.87)$ & $1.40(1.10 ; 1.77)$ \\
\hline $\begin{array}{l}\text { Not working or other } \\
\text { condition } x \text { child's age }{ }^{b}\end{array}$ & $0.69(0.59 ; 0.81)$ & $0.71(0.60 ; 0.84)$ & $0.88(0.49 ; 1.61)$ & $0.90(0.46 ; 1.74)$ & $0.29(0.14 ; 0.59)$ & $0.32(0.15 ; 0.68)$ \\
\hline \multicolumn{7}{|l|}{ Health assistance } \\
\hline Paediatrician & ref & ref & ref & ref & ref & ref \\
\hline $\begin{array}{l}\text { Primary health care } \\
\text { physician }\end{array}$ & $1.08(0.89 ; 1.32)$ & $0.90(0.72 ; 1.13)$ & $0.93(0.78 ; 1.11)$ & $0.93(0.76 ; 1.14)$ & $2.01(1.55 ; 2.61)$ & $1.70(1.26 ; 2.29)$ \\
\hline Both & $0.98(0.81 ; 1.19)$ & $0.91(0.74 ; 1.12)$ & $1.00(0.84 ; 1.18)$ & $1.01(0.84 ; 1.21)$ & $1.46(1.13 ; 1.89)$ & $1.49(1.12 ; 1.97)$ \\
\hline \multicolumn{7}{|l|}{ Child's chronic disease $^{c}$} \\
\hline No & ref & ref & ref & ref & ref & ref \\
\hline Yes & $1.02(0.80 ; 1.30)$ & $1.07(0.82 ; 1.39)$ & $0.96(0.78 ; 1.18)$ & $0.98(0.78 ; 1.23)$ & $0.76(0.56 ; 1.03)$ & $0.76(0.56 ; 1.06)$ \\
\hline
\end{tabular}

${ }^{a}$ Model adjusted for child sex, mother's age and educational level, living with siblings, health assistance and disease; In the case of the variable mother's employment status, the model is adjusted for all variables except mother's educational level

b Additional adjustment for the interaction between mothers' education or employment status and children's age

${ }^{\circ}$ Disease that requires regular medical care

than 30 years old $(\mathrm{HR}=0.77,95 \% \mathrm{Cl}=0.61 ; 0.99)$. The risk o of $\mathrm{BF}$ cessation was higher in more educated mother's when compared to children whose mothers do not have a higher education, even though not significant. However, for later child ages, the risk of BF cessation significantly increases for higher educated mothers $(H R=1.46$, $95 \% \mathrm{Cl}=1.24 ; 1.72)$. The unemployment situation had a protective effect for $\mathrm{BF}$ cessation $(\mathrm{HR}=0.62,95 \% \mathrm{Cl}=0.45 ; 0.85)$, also having a significant decreasing effect as the child's age increases $(H R=0.71$, $95 \% \mathrm{Cl}=0.60 ; 0.84)$, when compared with employed mothers.

Early introduction of cow milk ( $<12$ months) was significantly higher in children living with siblings ( $\mathrm{HR}=1.32,95 \% \mathrm{Cl}=1.06 ; 1.64)$. Unemployed mothers also had higher risk of early introduction to cow milk ( $\mathrm{HR}=1.40$, $95 \% \mathrm{Cl}=1.10 ; 1.77)$ when compared to children whose mothers were employed, although the risk was attenuated as the age of the children increases ( $\mathrm{HR}=0.32,95 \% \mathrm{Cl}=0.15 ; 0.68)$. The risk of early introduction of cow milk was also $70 \%$ higher in children assisted by the primary health care physician $(\mathrm{HR}=1.70,95 \% \mathrm{Cl}=1.26 ; 2.29)$ and $49 \%$ higher in children assisted by both the primary health care physician or and the paediatrician $(\mathrm{HR}=1.49,95 \% \mathrm{Cl}=1.12 ; 1.97)$, when compared with children assisted by the paediatrician. On the other hand, children with mothers with a higher education presented a 35\% lower risk of early cow milk introduction, when compared with less educated mothers ( $\mathrm{HR}=0.65,95 \% \mathrm{Cl}=0.50 ; 0.85)$, however as the child's age increases, the differences between classes (employed vs. unemployed) are attenuated.

None of the studied variables revealed an association with the time of introduction of complementary feeding (Table 3).

Time of complementary feeding significantly differed according to the use or non-use of infant formulas, and the introduction of cow milk significantly differed according to EBF (Figure 1). Mothers who used infant formulas before 4 months, started earlier the complementary feeding and mothers who breastfed exclusively less than 4 months, more frequently introduced cow milk before 12 months of age.

\section{DISCUSSION}

In a national representative sample of children aged between 3 and 35 months, the prevalence of breastfeeding initiation was high (94\%) but mostly for less than one year ( $65 \%$ of dropout). Only $21 \%$ of children were exclusively breastfed until 6 months Complementary feeding practice seems to happen according to recommendations, starting between 4 and 6 month of age in most cases, and by a vegetable soup (66\%).

This study concludes that approximately $6 \%$ of children were never breastfed, a higher proportion than reported in an analysis of data from 26 Portuguese hospitals describing a prevalence of no BF until the day of hospital discharge of 1.4\% in 2013 (22). Last data of OCDE (2005) 
Survival curves for beginning of complementary feeding in children's diet as event of interest stratified by use of infant formula (top) and for cow milk introduction stratified by exclusive breastfeeding habits (bottom)


puts Portugal in a positive situation about the proportion of children that were ever breastfed, being above the average of EU-countries (23). More recent data reveals that in England and France, 23.8\% and $26.3 \%$ of children were never breastfed, respectively (24). In the present study, most children (65\%) were breastfed for less than one year of age, approaching the American Paediatric Society (8) and ESPGHAN (4) recommendations, even thought for a shorter period than the proposed by $\mathrm{WHO}$ (3). According to the current results, $30 \%$ of children stopped $\mathrm{BF}$ before 4 months. The European average, among WHO country members, is 33\% and the prevalence of EBF varies between $6 \%$ and $66 \%$ until 4 months of age (25). Besides its protective effect for the child and the mother (4), BF seems to be associated with healthy eating habits during infancy, since shorter BF duration was associated with lower vegetable consumption (26) and with less healthy and less varied diets between 2 and 4 years of age, among European birth cohorts (24). Previous results from the EPACl study held in 2012 (27), including a national sample of mainland Portuguese population until 36 months, showed a prevalence of breastfeeding initiation of $90 \%$, and $20.6 \%$ of exclusive breastfeeding until 6 months.

In our sample, higher maternal education was associated with a lower duration of $\mathrm{BF}$, which is not observed in previous literature $(14,15,28,29)$. This fact could be associated with the Portuguese legislation concerning maternity leaving, which may be the cause of an earlier return to work by more educated mothers, influencing the cessation of BF during this period.

The fact that children with mothers, older than 35 years, had longer
BF duration may be explained by multiparity. A North American study revealed that a previous long-duration $B F$ experience has a positive influence in BF duration in the following pregnancy (30). Another study in a Danish population concludes that, besides having long BF previous experiences, self-efficacy perception about BF could increase its duration (31) and that more educated mothers seem to feel more competent about BF than less educated mothers, therefore feeling more capable of dealing with difficulties (32). Therefore, guiding and promoting longer periods of $\mathrm{BF}$ at first pregnancy is beneficial not only for the child but also for future pregnancies (30). One way to promote $\mathrm{BF}$ for a longer period of time is to promote feelings and confidence and efficiency, what could be essential in cases of reduced experience (32) as primiparous mothers. Moreover, employment status has been considered as an important influencing factor in non-breastfeeding or early beginning of complementary feeding (33). In Portugal, the maternity leave duration is for 4 months with full wage or 5 months with a monthly wage reduction of $20 \%$. A previous study in Portuguese northern population supports that 5 months of maternity leave increases the BF duration (34). Thus, higher maternity availability seems to be associated with an increase of BF duration, which is in agreement with the results obtained for unemployed mothers in this study.

In Portuguese children, complementary feeding starts mostly during the recommended period, between the 4th and the 6th months of life (7). However, 3.3\% of children started complementary feeding before 4 months, age in which children are not physiologically prepared to solid foods (7). Moreover, it has been associated with an increased 
risk of allergy (35), overweight and obesity (36), when compared with starting complementary feeding at the recommended age.

The food reported as first food in complementary feeding was the vegetable soup (66.3\%), even higher percentage than reported in 2012 (52.5\%) (27). Portugal has a long tradition of vegetable soup consumption that could help to support this decision regarding young children's diet.

According to the ESPGHAN recommendation(7), meat should be introduced to infants at 6 months of age in order to avoid inadequacy of iron, since the iron reserves start to run out between the 4 th and the 6 th months (6). However, $25 \%$ of the children only introduced meat after the age of 8 months. The fish introduction was also delayed beyond the recommended timing for $25 \%$ of children.

The consumption of fruit juices, fruit nectars, breakfast cereals, desserts, and soft drinks happened, mostly, after one year of age, which may be associated with the integration into the family diet (6). As described previously, $10 \%$ of children have started with soft drinks before 12 months and at 30 months $50 \%$ of children have already tasted this type of sugary beverages. In the US population, the situation is even worse, where soft drinks are among the main carbohydrates sources after the 11th month of age, representing the third higher energy source between the age of 12 and 24 months (37). Besides the high energy density, this could enhance the innate preference for sweet taste (7).

According to previous literature, lower maternal literacy, younger motherhood, lower socioeconomic status and lower BF duration are factors often associated with the early start of complementary feeding (13). In our study, none of the studied factors has shown to be associated with the age of complementary feeding beginning which might be explained by the lower prevalence of children who started complementary feeding before 4 months.

In the present study, it was also observed that $6.5 \%$ of children introduced cow milk before 12 months of age, which according to the literature predisposes children to a higher risk of anaemia (10). Cow milk is generally a less expensive alternative to infant formula, so when early introduced should be considered in a context of a balanced diet with other sources of iron (10), and be aware for not exceeding the adequate daily protein intake.

Children whose mothers were unemployed had a higher risk of early cow milk introduction, in contrast to more educated mothers. A systematic review (13) supports this relationship but did not find an association with children living with siblings, as found in this study. Child' health assistance also seems to influence the age of cow milk introduction. Even after adjustment for sociodemographic variables, children exclusively followed by the primary health care physician, compared with children exclusively followed by the paediatrician, had $70 \%$ more risk of early introduction and, if assisted by both, the increased risk was of $49 \%$. We could hypothesized that children followed at the primary health care system were less frequently followed, but additional studies need to be performed to clarify this.

This study has the advantage of including a representative sample of children, although without regional representativeness that could be important in future studies. Data collection was made by trained interviewers with Nutrition background and following standardize procedures.

The cross-sectional nature of this study difficult the estimation of the prevalence among the different age groups, sometimes even for events that were not expected to happen until a certain age. However, it was overtaken using survival analysis, a methodology capable of leading with different periods of exposure. This study is inside a national survey with large age spectrum, not specifically designed for children in the age groups defined in this study, which somehow limited the study of other early eating practices determinants.

In conclusion, among the Portuguese population, the early feeding practices happen in general according to recommendations. Early breastfeeding cessation is more frequent among more educated and employed mothers. Other practices that could compromise child's healthy growth as the early cow milk introduction are more frequent in lower socioeconomic families. Thus, feeding practices during over the first few years could be influenced by several factors that should be considered in child health promotion and definition of healthy public policies.

\section{REFERENCES}

1. Binns C, Lee M, Low WY. The long-term public health benefits of breastfeeding Asia Pacific Journal of Public Health. 2016;28(1):7-14.

2. Siega-Riz AM, Deming DM, Reidy KC, Fox MK, Condon E, Briefel RR. Food consumption patterns of infants and toddlers: where are we now? Journal of the American Dietetic Association. 2010;110(12):S38-S51.

3. Organization WH. The optimal duration of exclusive breastfeeding. Report of an Expert Consultation. . Geneva, Switzerland: World Health Organization; 2001.

4. Agostoni C, Braegger C, Decsi T, Kolacek S, Koletzko B, Michaelsen KF, et al. Breast-feeding: a commentary by the ESPGHAN Committee on Nutrition. Journal of pediatric gastroenterology and nutrition. 2009;49(1):112-25.

5. Agostoni C, Bergman R, Bresson J-L, Michaelsen KF, Przyrembel H, Sanz Y, et al. Scientific opinion on the appropriate age for introduction of complementary feeding of infants: EFSA panel on dietetic products, nutrition and allergies (NDA). EFSA Journal. 2009;7(12).

6. Guerra A, Rêgo C, Silva D, Ferreira GC, Mansilha H, Antunes H, et al. Alimentação e nutrição do lactente. Acta Pediátrica Portuguesa. 2012;43(5):S17-S40.

7. Fewtrell M, Bronsky J, Campoy C, Domellöf M, Embleton N, Mis NF, et al. Complementary feeding: a position paper by the European Society for Paediatric Gastroenterology, Hepatology, and Nutrition (ESPGHAN) Committee on Nutrition. Journal of pediatric gastroenterology and nutrition. 2017;64(1):119-32.

8. Eidelman Al, Schanler RJ, Johnston M, Landers S, Noble L, Szucs K, et al. Breastfeeding and the use of human milk. Pediatrics. 2012;129(3):e827-e41.

9. Organization WH. Complementary Feeding. Report of the Global Consultation. Geneva, 10-13 December 2001. Summary of Guiding Principles. Geneva, Switzerland: World Health Organization; 2002.

10. Griebler U, Bruckmüller MU, Kien C, Dieminger B, Meidlinger B, Seper K, et al. Health effects of cow's milk consumption in infants up to 3 years of age: a systematic review and meta-analysis. Public health nutrition. 2016;19(2):293-307.

11. Ziegler EE. Adverse effects of cow's milk in infants. Issues in Complementary Feeding. 60: Karger Publishers; 2007. p. 185-99.

12. Ziegler EE. Consumption of cow's milk as a cause of iron deficiency in infants and toddlers. Nutrition reviews. 2011;69(s1).

13. Wijndaele K, Lakshman R, Landsbaugh JR, Ong KK, Ogilvie D. Determinants of early weaning and use of unmodified cow's milk in infants: a systematic review. Journal of the Academy of Nutrition and Dietetics. 2009;109(12):2017-28.

14. Hendricks K, Briefel R, Novak T, Ziegler P. Maternal and child characteristics associated with infant and toddler feeding practices. Journal of the Academy of Nutrition and Dietetics. 2006;106(1):135-48.

15. Bertini G, Perugi S, Dani C, Pezzati M, Tronchin M, Rubaltelli FF. Maternal education and the incidence and duration of breast feeding: a prospective study. Journal of pediatric gastroenterology and nutrition. 2003;37(4):447-52.

16. Doub AE, Moding KJ, Stifter CA. Infant and maternal predictors of early life feeding decisions. The timing of solid food introduction. Appetite. 2015;92:261-8.

17. Saldan PC, Venancio SI, Saldiva SRDM, Vieira DG, Mello DFd. MILK CONSUMPTION IN INFANTS UNDER ONE YEAR OF AGE AND VARIABLES ASSOCIATED WITH NONMATERNAL MILK CONSUMPTION. Revista Paulista de Pediatria. 2017;35(4):407-14. 18. Lopes C, Torres D, Oliveira A, Severo M, Guiomar S, Alarcão V, et al. National 
Food, Nutrition and Physical Activity Survey of the Portuguese general population. EFSA Supporting Publications. 2017;14(12):1341E.

19. Lopes C, Torres D, Oliveira A, Severo M, Guiomar S, Alarcão V, et al. National Food, Nutrition, and Physical Activity Survey of the Portuguese General Population (20152016): Protocol for Design and Development. JMIR research protocols. 2018;7(2). 20. European Food Safety Authority. Guidance on the EU Menu methodology. EFSA Journal 2014; 12(12): 3944-77.

21. Organization WH. Training Course on Child Growth Assessment: Interpreting Growth Indicators. Geneva: WHO; 2008.

22. Orfao A, Santos Á, Gouveia C, Santos C, Chastre L. Registo do Aleitamento Materno | Relatório janeiro a dezembro 2013. 2014.

23. OECD - Social Policy Division - Directorate of Employment LaSA. C01.5: Breastfeeding rates. 2009.

24. Jones L, Moschonis G, Oliveira A, de Lauzon-Guillain B, Manios Y, Xepapadaki P, et al. The influence of early feeding practices on healthy diet variety score among pre-school children in four European birth cohorts. Public health nutrition. 2015;18(10):1774-84 25. Bosi ATB, Eriksen KG, Sobko T, Wijnhoven TM, Breda J. Breastfeeding practices and policies in WHO European region member states. Public health nutrition. 2016;19(4):753-64.

26. de Lauzon-Guillain B, Jones L, Oliveira A, Moschonis G, Betoko A, Lopes C, et al. The influence of early feeding practices on fruit and vegetable intake among preschool children in 4 European birth cohorts. The American journal of clinical nutrition. 2013;98(3):804-12.

27. Rêgo C, Lopes C, Pinto E, Nazareth M, Graça P. Alimentação e crescimento nos primeiros anos de vida: a propósito do EPACl Portugal 20122013 [Available from: https://www.alimentacaosaudavel.dgs.pt/activeapp/wp-content/files_ mf/1445005594EPACl2013.pdf.

28. Scott J, Landers M, Hughes R, Binns C. Factors associated with breastfeeding at discharge and duration of breastfeeding. Journal of paediatrics and child health. 2001;37(3):254-61.

29. Sutherland T, Pierce CB, Blomquist JL, Handa VL. Breastfeeding practices among first-time mothers and across multiple pregnancies. Maternal and child health journal. 2012;16(8):1665-71.

30. Bai DL, Fong DYT, Tarrant M. Previous breastfeeding experience and duration of any and exclusive breastfeeding among multiparous mothers. Birth. 2015;42(1):70-7. 31. Kronborg $\mathrm{H}$, Vaeth $\mathrm{M}$. The influence of psychosocial factors on the duration of breastfeeding. Scandinavian Journal of Public Health. 2004;32(3):210-6.

32. Dennis CLE. Identifying predictors of breastfeeding self-efficacy in the immediate postpartum period. Research in nursing \& health. 2006;29(4):256-68.

33. Rollins NC, Bhandari N, Hajeebhoy N, Horton S, Lutter CK, Martines JC, et al. Why invest, and what it will take to improve breastfeeding practices? The Lancet. 2016;387(10017):491-504.

34. Lanzaro C, Santos P, Guerra A, Hespanhol AP, Esteves MJ. Prevalência do aleitamento materno: Comparação entre uma população urbana e uma população rural do norte de Portugal. Ata Pediátrica Portuguesa. 2015;46:101-8.

35. Muraro A, Halken S, Arshad SH, Beyer K, Dubois AEJ, Toit GD, et al. EAACI Food Allergy and Anaphylaxis Guidelines. Primary prevention of food allergy. Allergy. 2014;69(5):590-601.

36. Wang J, Wu Y, Xiong G, Chao T, Jin Q, Liu R, et al. Introduction of complementary feeding before 4 months of age increases the risk of childhood overweight or obesity: A meta-analysis of prospective cohort studies. Nutrition Research. 2016;36(8):759-70. 37. Fox MK, Reidy K, Novak T, Ziegler P. Sources of energy and nutrients in the diets of infants and toddlers. Journal of the American Dietetic Association. 2006;106(1):28. e1-. e5. 